Article

\title{
Investigation of the Effects of Perfluorooctanoic Acid (PFOA) and Perfluorooctane Sulfonate (PFOS) on Apoptosis and Cell Cycle in a Zebrafish (Danio rerio) Liver Cell Line
}

\author{
Yuan Cui, Wei Liu, Wenping Xie, Wenlian Yu, Cheng Wang and Huiming Chen * \\ Received: 9 June 2015; Accepted: 26 November 2015; Published: 9 December 2015 \\ Academic Editor: Paul B. Tchounwou \\ Chinese Academy of Inspection and Quarantine, Beijing 100123, China; cuiy@aqsiqch.ac.cn (Y.C.); \\ liuw@aqsiqch.ac.cn (W.L.); xiewp@aqsiqch.ac.cn (W.X.); yuwl@aqsiqch.ac.cn (W.Y.); \\ wangz@aqsiqch.ac.cn (C.W.) \\ * Correspondence: chenhm@aqsiqch.ac.cn; Tel./Fax: +86-10-5389-7808
}

\begin{abstract}
This study aimed to explore the effects of perfluorooctanoic acid (PFOA) and perfluorooctane sulfonate (PFOS) on apoptosis and cell cycle in a zebrafish (Danio rerio) liver cell line (ZFL). Treatment groups included a control group, PFOA-IC $C_{50}, \mathrm{PFOA}_{\mathrm{IC}} \mathrm{I}_{80}, \mathrm{PFOS}_{\mathrm{IC}} \mathrm{IC}_{50}$ and PFOS-IC 80 groups. $\mathrm{IC}_{50}$ and $\mathrm{IC}_{80}$ concentrations were identified by cellular modeling and MTT assays. mRNA levels of p53, Bcl-2, Bax, Caspase-3 and NF- $\mathrm{kB}$ p65 were detected by qPCR. Cell apoptosis and cell cycle were detected by flow cytometry and the protein levels of p53, Bcl-2, Bax, Caspase- 3 and NF- $\mathrm{KB}$ p65 were determined by western blotting. Both PFOA and PFOS inhibited the growth of zebrafish liver cells, and the inhibition rate of PFOS was higher than that of PFOA. Bcl-2 expression levels in the four groups were significantly higher than the control group and Bcl-2 increased significantly in the PFOA-IC 80 group. However, the expression levels of Bax in the four treatment groups were higher than the control group. The percentage of cell apoptosis increased significantly with the treatment of PFOA and PFOS $(p<0.05)$. Cell cycle and cell proliferation were blocked in both the PFOA-IC 80 and PFOS-IC 80 groups, indicating that $\mathrm{PFOA}-\mathrm{IC}_{80}$ and $\mathrm{PFOS}_{8} \mathrm{IC}_{50}$ enhanced apoptosis in ZFL cells.
\end{abstract}

Keywords: perfluorooctanoic acid (PFOA); perfluorooctane sulfonate (PFOS); zebrafish liver cells (ZFL); apoptosis

\section{Introduction}

Multicellular animals dispose of unneeded or damaged cells in an ordered fashion by apoptosis [1]. Apoptosis is a programmed cell death pathway that removes damaged cells to protect the body, and it is especially important in vertebrate embryonic development [2]. The relationship between stress-induction and apoptosis during the development has been confirmed by experimental studies using zebrafish (Danio rerio) embryos, and researches on apoptotic genes, including the Bcl-2 gene family, p53, and the caspase family, are still under the spotlight [3-6]. Many apoptosis related genes in mammals were first identified in zebrafish, which implies the high degree of conservation within the apoptosis pathway across species [7]. Accordingly, zebrafish is considered to be an effective animal model to reveal the relationship between stress-induction and apoptosis.

Perfluorinated chemicals (PFCs) are synthesized fluorinated compounds composed of a carbon backbone that is typically $4-14$ atoms in length and a charged moiety, primarily a carboxylate or sulfonate. Perfluorooctanoic acid (PFOA) and perfluorooctane sulfonate (PFOS) are two of the most widely used PFCs. PFOA and PFOS have already been considered as emerging persistent 
organic pollutants [8]. The distribution of PFOA and PFOS in the environment has increased universally in recent years [9] and their accumulation and toxic effects have become serious issues to be addressed [10]. PFOS and PFOA are important PFCs with hydrophobic and oleophobic properties [11], which are widely used in carpet, leather, paper, and fiber manufacture, as well as the textile industry and other consumer products.

Previous studies have reported on the toxicology of PFOA and PFOS. PFOA and PFOS can be found in the liver, serum and other tissues of humans and animals [12]. For rats chronic exposure to PFOA and PFOS is associated with tumor development in the liver, pancreas and testis [13-15]. Furthermore, PFOS has been reported to induce in vivo hepatocellular hypertrophy, lipid vacuolation, loss of body weight, and lower serum total cholesterol in monkeys [16]. Guruge et al. found that gene regulation related with cell communication, growth and apoptosis, and fatty acid metabolisms in rats after exposure to PFOA [17]. In addition, PFOA had a toxic effect on the liver, not on the kidney, in mice exposed to PFOA in their drinking water [18].

Mechanistically, some reports showed that PFOA induced apoptosis in a dose- and time-dependent manner in hepatoma HepG2 cells $[19,20]$. Moreover, genotoxic risk and oxidative DNA damage was reported in HepG2 cells exposed to PFOA [21]. Similarly, Liu et al. demonstrated that PFOA and PFOS were individually able to produce oxidative stress and induce apoptosis through the involvement of caspases in primary cultured tilapia (Oreochromis niloticus) hepatocytes [22].

However, there has been no investigation into the effects of PFOA and PFOS on apoptosis in the zebrafish liver cell line (ZFL). In this study, accordingly, we aimed to detect the mRNA and protein levels of apoptosis related genes in ZFL and to explore the mechanisms how PFOA and PFOS mediate apoptosis in ZFL.

\section{Materials and Methods}

\subsection{ZFL Culture}

ZFL was obtained from American Type Culture Collection (ATCC, Rockville, MD, USA). The cell line was cultured in a medium consisted of 50\% Leibovitz L-15 (Gibco BRL Co. Ltd. Gaithersburg, MD, USA), 15\% Ham F-12 (Gibco) and 35\% Dulbecco's modified eagle medium (DMEM; Gibco), supplemented with $50 \mathrm{ng} / \mathrm{mL}$ epidermal growth factor (EGF; Gibco), $0.01 \mathrm{mg} / \mathrm{mL}$ insulin (Sigma), $15 \mathrm{mM}$ 4-(2-hydroxyethyl)-1-piperazineethanesulfonic acid (HEPES; Gibco) and 5\% fetal bovine serum (FBS; Gibco) at $37{ }^{\circ} \mathrm{C}$ and saturated with $5 \% \mathrm{CO}_{2}$ in a humidified atmosphere. Next, $10 \%$ dimethyl sulfoxide (DMSO) and 90\% FBS were suspended as cell freezing medium. All the ZFL cells were recovered in a conventional method and observed [23]. The ZFL cells were seeded on 96-well plates with a cell density of $1 \times 10^{4}$ per well and incubated overnight to achieve a $85 \%$ confluence, and then the cells were sub-cultured and frozen.

\subsection{Cellular Modeling and MTT Assay}

$50 \%$ inhibitory concentration ( $\left.\mathrm{IC}_{50}\right)$ and $80 \%$ inhibitory concentration $\left(\mathrm{IC}_{80}\right)$ were measured by MTT assays. ZFL cells were treated with 100, 50, 25, 12.5, 6.25, 3.125, 1.062, 0.53, 0.2605, 0.130, 0.065 and $0 \mu \mathrm{g} / \mathrm{mL}$ of PFOA or PFOS for $48 \mathrm{~h}$, respectively. Cells were incubated for $4 \mathrm{~h}$ after $100 \mu \mathrm{L}$ serum-free medium and $10 \mu \mathrm{L}$ MTT were added. ODs were detected at $490 \mathrm{~nm}$ after the $100-\mu \mathrm{L}$ solubilization buffer $(10 \%$ SDS $+0.01 \mathrm{M} \mathrm{HCl})$ was added.

\subsection{Quantitative Real Time-Polymerase Chain Reaction ( $q P C R$ )}

Total RNA was extracted using a RNA Extraction Kit according to the manufacturer's instructions (CWbio, Beijing, China). Reverse transcription was performed by HiFi-MMLVcDNA (KITCWbio. Co. Ltd., Beijing, China). The PCR conditions were as follows: 45 cycles at $95{ }^{\circ} \mathrm{C}$ for $10 \mathrm{~min}, 95^{\circ} \mathrm{C}$ for $15 \mathrm{~s}$ and $60{ }^{\circ} \mathrm{C}$ for $60 \mathrm{~s}$ successively. $\beta$-Actin was used as an internal control in 
the experiment. All reactions were completed in triplicate using independently-extracted RNA and the relative expression levels were detected by fluorescence ratio PCR instrument (ABI 7500) and calculated using the $2^{-\Delta \Delta C t}$ comparative CT method. Gene-specific primers for qPCR are listed in Table 1.

\subsection{Flow Cytometry of Cell Apoptosis Detection}

Annexin V-FITC-PI kit (Beijing 4A Biotech Co., Ltd., Beijing, China) was used for detecting cell apoptosis by flow cytometry. Annexin $\mathrm{V}$ is a $\mathrm{Ca}^{2+}$-dependent phospholipid-binding protein that has a high affinity for phospholipid phosphatidylserine (PS), and is useful for identifying apoptotic cells with exposed PS. Propidium iodide (PI) is a standard flow cytometric viability probe and is used to distinguish viable from nonviable cells, as intact membranes of viable cells exclude PI while membranes of dead or damaged cells are permeable to PI. Briefly, single-cell suspension of $1 \times 10^{6}$ cells was added into a $1.5-\mathrm{mL}$ centrifuge tube, centrifuged at $300 \times g$ for $5 \mathrm{~min}$, and the supernatant was discarded. Afterwards, $1 \mathrm{~mL}$ of PBS was added to the cell pellet, and the samples were centrifuged at $300 \times g$. This above washing procedure was repeated twice. Subsequently, $100 \mu \mathrm{L}$ of binding buffer, $5 \mu \mathrm{L}$ Annexin V-FITC and $10 \mu \mathrm{L}$ PI were added and the samples were incubated at room temperature for $15 \mathrm{~min}$, ensuring no exposure to light. Finally, $400 \mu \mathrm{L}$ binding buffer was added to the samples and cell apoptosis was detected by flow cytometry. A software package called Cellquest was used to analyze cell apoptosis.

Table 1. Primer sequences for RT-PCR.

\begin{tabular}{|c|c|c|}
\hline Primer & Sequences $\left(5^{\prime}\right.$ to $\left.3^{\prime}\right)$ & PCR Fragments (bp) \\
\hline $\begin{array}{l}\text { P53 forward primer } \\
\text { P53 reverse primer }\end{array}$ & $\begin{array}{l}\text { CCACCATGAGAGAACACCTGAT } \\
\text { GCTGAGGAGCTTCATAGAGAACC }\end{array}$ & 144 \\
\hline $\begin{array}{l}\mathrm{Bcl}-2 \text { forward primer } \\
\mathrm{Bcl}-2 \text { reverse primer }\end{array}$ & $\begin{array}{l}\text { TGGGCTCATCTCCTTCTCC } \\
\text { TCTCCTCACAGCTCCACATC }\end{array}$ & 178 \\
\hline $\begin{array}{l}\text { Bax forward primer } \\
\text { Bax reverse primer }\end{array}$ & $\begin{array}{l}\text { GGAGGCGATACGGGCAGT } \\
\text { TTGCGAATCACCAATGCTGTG }\end{array}$ & 151 \\
\hline $\begin{array}{l}\text { Caspase- } 3 \text { forward primer } \\
\text { Caspase-3 reverse primer }\end{array}$ & $\begin{array}{l}\text { ACTGATGGTTCTGTGGAGC } \\
\text { CGCATAGAGGAAGTCTGCTT }\end{array}$ & 200 \\
\hline $\begin{array}{l}\text { NFKBNF- } \kappa B \text { p } 65 \text { forward primer } \\
\text { NFKBNF- } \kappa B \text { p } 65 \text { reverse primer }\end{array}$ & $\begin{array}{l}\text { AAGATGAGAACGGAGACACGC } \\
\text { TACCAGCAATCGCAAACAACG }\end{array}$ & 404 \\
\hline $\begin{array}{l}\text { B-actin forward primer } \\
\beta \text {-actin reverse primer }\end{array}$ & $\begin{array}{l}\text { CAGGGCGTGATGGTGGGGAT } \\
\text { GGTTGGCTTTGGGGTTGAG }\end{array}$ & 226 \\
\hline $\begin{array}{l}\text { GAPDH forward primer } \\
\text { GAPDH reverse primer }\end{array}$ & $\begin{array}{l}\text { AGTTGTAAGCAATGCCTCCTG } \\
\text { CTGGGATGATGTTCTGACTGG }\end{array}$ & 191 \\
\hline $\begin{array}{l}\text { B2M forward primer } \\
\text { B2M reverse primer }\end{array}$ & $\begin{array}{l}\text { GCACTCATCACTTTTGCACTTC } \\
\text { GCTCACATAGCAGATCAGGGT }\end{array}$ & 135 \\
\hline
\end{tabular}

\subsection{Cell Cycle Analysis}

$4 \times 10^{5}$ cells were seeded into 6-well plates, synchronized by serum starvation for $24 \mathrm{~h}$, and re-entered into the cell cycle by an exchange of a medium with 10\% FBS DMEM for $24 \mathrm{~h}$. Both adherent and non-adherent cells were harvested and fixed in $70 \%$ ethanol at $4{ }^{\circ} \mathrm{C}$ overnight. Cells were incubated with RNase A at $37^{\circ} \mathrm{C}$ for $30 \mathrm{~min}$ and then stained with PI. Cell cycle status was measured by flow cytometry.

\subsection{Western Blot Assay}

Cells were lysed with RIPA buffer and the proteins lysates were separated using $12 \%$ SDS-PAGE. The proteins were transferred onto a PVDF membrane for $1 \mathrm{~h}$ and then the membrane was incubated with primary antibody overnight at $4{ }^{\circ} \mathrm{C}$ after being blocked with $3 \%$ BSA-TBST solution for $30 \mathrm{~min}$. The membrane was washed with TBST solution three times, 10 min each time. Then the membrane 
was incubated with secondary antibody (Beijing TDY Biotech Co., Ltd., Beijing, China) for $2 \mathrm{~h}$ at room temperature. Finally, the membrane was developed after being washed again with TBST solution three times, 10 min each time. The protein expressions of p53 (Beijing TDY Biotech Co., Ltd.), Caspase 3 (Abcam, Cambridge, UK) and Bcl-2 (Beijing TDY Biotech Co., Ltd.) were detected by western blotting. GAPDH (Beijing TDY Biotech Co., Ltd.) and B2M (Beijing TDY Biotech Co., Ltd.) were used as an internal control for the experiment.

\subsection{Statistical Analysis}

Statistical analysis was performed using the software package SPSS 13.0 (SPSS, Inc., Chicago, IL, USA) Data are represented as the mean value and statistical significance was determined by one-way ANOVA. Differences were considered significant at $p<0.05$.

\section{Results}

\subsection{Detection of $I C_{50}$ and $I C_{80}$ Concentrations}

To determine the $\mathrm{IC}_{50}$ and $\mathrm{IC}_{80}$ concentrations of PFOA and PFOS, ZFL cells were treated with different concentrations of PFOA or PFOS, and the inhibition rate was determined by an MTT assay (see Figure 1). As shown in Figure 1, both PFOA and PFOS could inhibit zebrafish liver cells. Moreover, the inhibition rate of PFOS was higher than that of PFOA. As summarized in Table 2, the $\mathrm{IC}_{50}$ and $\mathrm{IC}_{80}$ concentrations of PFOA were $84.76 \mu \mathrm{g} / \mathrm{mL}$ and $150.97 \mu \mathrm{g} / \mathrm{mL}$, respectively (the $\mathrm{IC}_{80}$ for PFOA was extrapolated) The $\mathrm{IC}_{50}$ and $\mathrm{IC}_{80}$ concentrations of PFOS were $27.92 \mu \mathrm{g} / \mathrm{mL}$ and $56.77 \mu \mathrm{g} / \mathrm{mL}$, respectively. The subsequent experiments were performed on $\mathrm{IC}_{50}$ and $\mathrm{IC}_{80}$ samples of PFOA and PFOS.

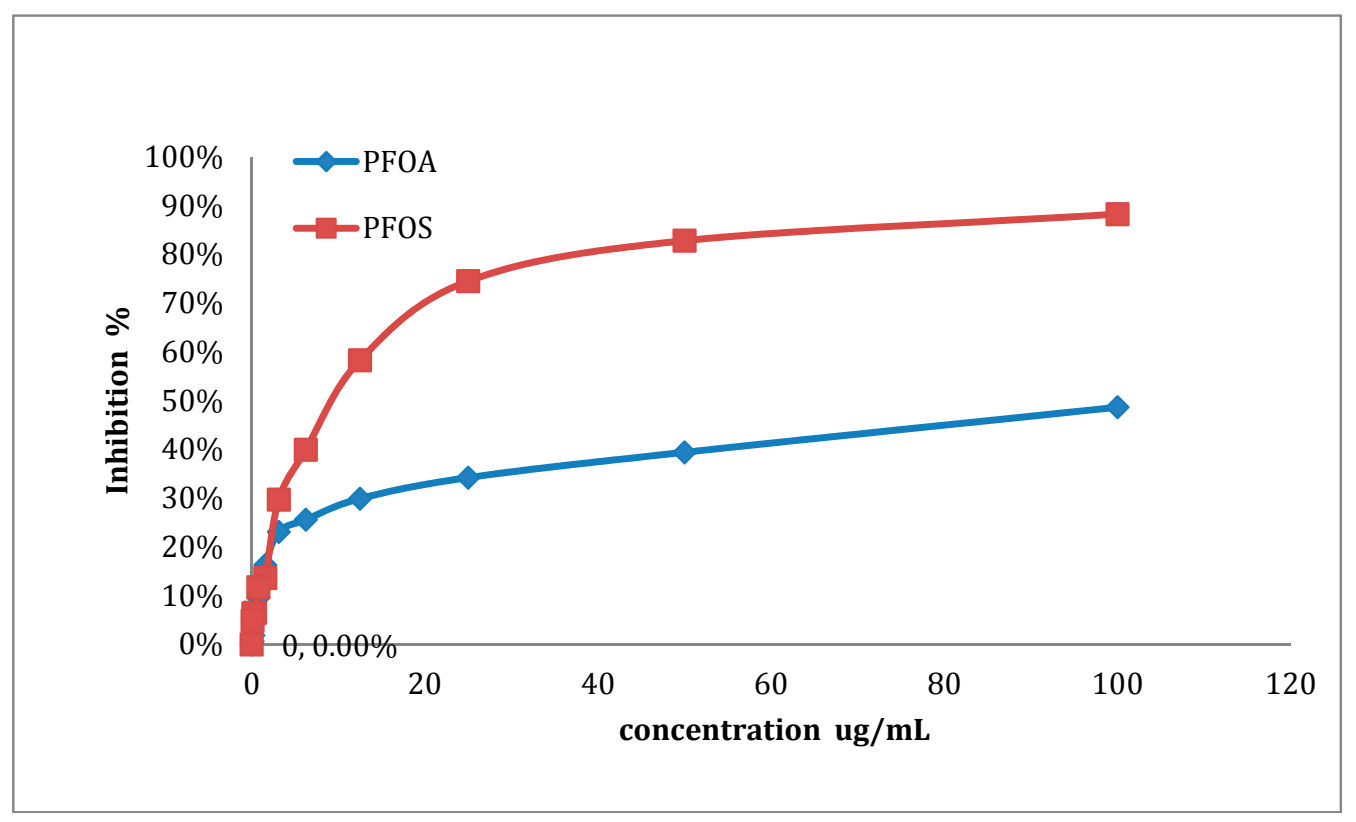

Figure 1. Inhibition rate of PFOS and PFOA in ZFL cells. ZFL cells were treated with $100 \mu \mathrm{g} / \mathrm{mL}$, $50,25,12.5,6.25,3.125,1.062,0.53,0.2605,0.130,0.065$ or $0 \mu \mathrm{g} / \mathrm{mL}$ of either PFOA or PFOS for $48 \mathrm{~h}$. The inhibition rate was determined by MTT assay.

Table 2. $\mathrm{IC}_{50}$ and $\mathrm{IC}_{80}$ of PFOA and PFOS.

\begin{tabular}{ccc}
\hline Substances & IC $_{\mathbf{5 0}}$ & IC $_{\mathbf{8 0}}$ \\
\hline PFOA $(\mu \mathrm{g} / \mathrm{mL})$ & 84.76 & 150.97 \\
PFOS $(\mu \mathrm{g} / \mathrm{mL})$ & 27.92 & 56.77 \\
\hline
\end{tabular}




\subsection{Relative Expression of p53, Bcl-2, Bax, Caspase-3 and NFKB p65}

qPCR was performed to determine whether PFOA and PFOS treatment affected the expression of apoptosis-related genes, such as p53, Bcl-2, Bax, Caspase-3 and NF- $\mathrm{kB}$ p65,. As shown in Figure 2, different relative levels of p53, Bcl-2, Bax, Caspase-3 and NF- $\mathrm{kB}$ p65 mRNA levels were induced

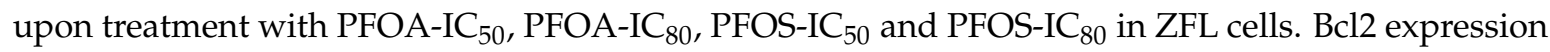
increased compared to the control group after PFOA and PFOS treatment, with the PFOS-IC 50 group exhibiting the highest induction. p53 had the highest expression in the $\mathrm{PFOA}-\mathrm{IC}_{50}$ group with an 8.709-fold induction. The mRNA level of Bax was induced with the treatment of PFOS, but was not induced with treatment of PFOA, and the PFOS-IC 50 and PFOS-IC80 groups exhibited comparable induction of Bax. For Caspase-3, the highest expression level was induced in the PFOA-IC 80 group. NF-KB p65 expression level was induced in all groups except the PFOA-IC 80 group. These results showed that PFOA and PFOS treatment could affect the expression of apoptosis related genes, including p53, Bcl-2, Bax, Caspase-3 and NF-kB p65.

(A)
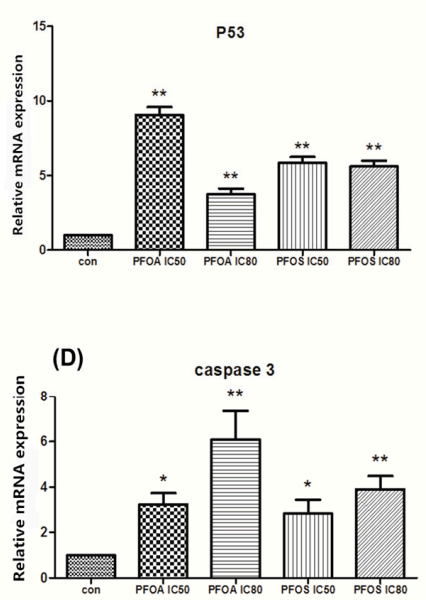

(B)

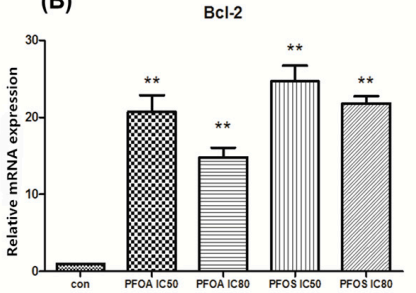

NFKB

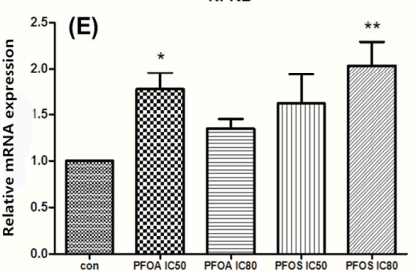

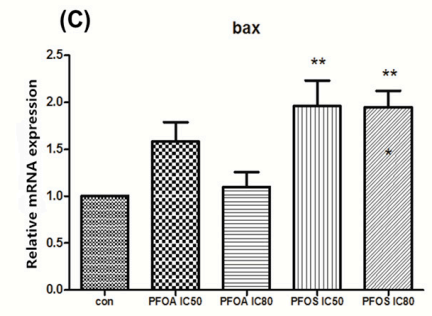

Figure 2. Relative gene expression of $\mathrm{p} 53, \mathrm{Bcl}-2$, Bax, Caspase-3 and NF-kB p65. ZFL cells were treated with PFOA or PFOS at $\mathrm{IC}_{50}$ or $\mathrm{IC}_{80}$ concentrations for $48 \mathrm{~h}$. $\beta$-actin was used as internal control. The experiment was repeated three times. ${ }^{*} p<0.05,{ }^{*} p<0.01$.

\subsection{Cell Apoptosis and Cycle in ZFL Cells}

Flow cytometry was used to detect the effects of PFOA and PFOS on apoptosis in ZFL cells. As shown in Figure 3, the percentage of cell apoptosis increased significantly after treatment with PFOA or PFOS in three independent experiments $(p<0.05)$. In addition, Figure 3 shows that the early apoptosis rate increased significantly in the PFOA-IC 50, PFOA-IC $_{80}$ and $\mathrm{PFOS}_{-\mathrm{IC}_{50}}$ groups. Moreover, significant promotion of late apoptosis was also observed in the $\mathrm{PFOA}^{-\mathrm{IC}_{80}}, \mathrm{PFOS}^{-\mathrm{IC}_{50}}$ and PFOS-IC 80 groups.

As shown in Figure 4, compared with the control group, the percentage of cells in G1/G0 phase decreased significantly $(p<0.01)$, and the percentage of cells in $\mathrm{G} 2 / \mathrm{M}$ phase and $\mathrm{S}$ phase increased significantly $(p<0.01)$ in both the PFOA-IC 80 group and the PFOS-IC 80 group. The results indicated that cell proliferation was blocked in both the groups. 

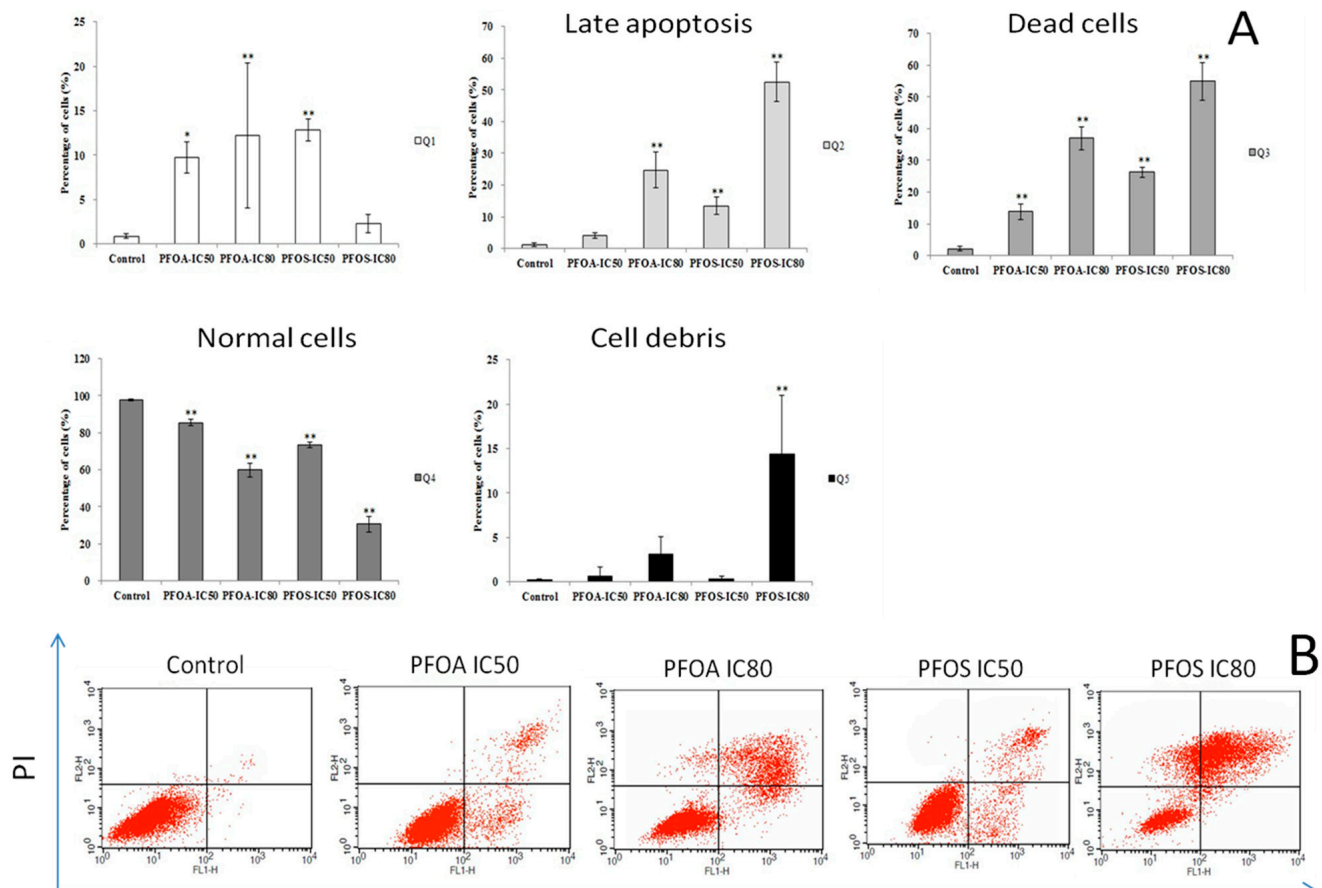

Annexin X

Figure 3. Detection of apoptosis on ZFL cells exposed to PFOA and PFOS using flow cytometry. ZFL cells were treated with PFOA or PFOS at $\mathrm{IC}_{50}$ or $\mathrm{IC}_{80}$ concentrations for $48 \mathrm{~h}$. Annexin V-FITC-PI kit was used for detecting cell apoptosis by flow cytometry. Percentage of cell apoptosis after treatment with PFOA or PFOS in three independent experiments. ${ }^{*} p<0.05,{ }^{* *} p<0.01$.
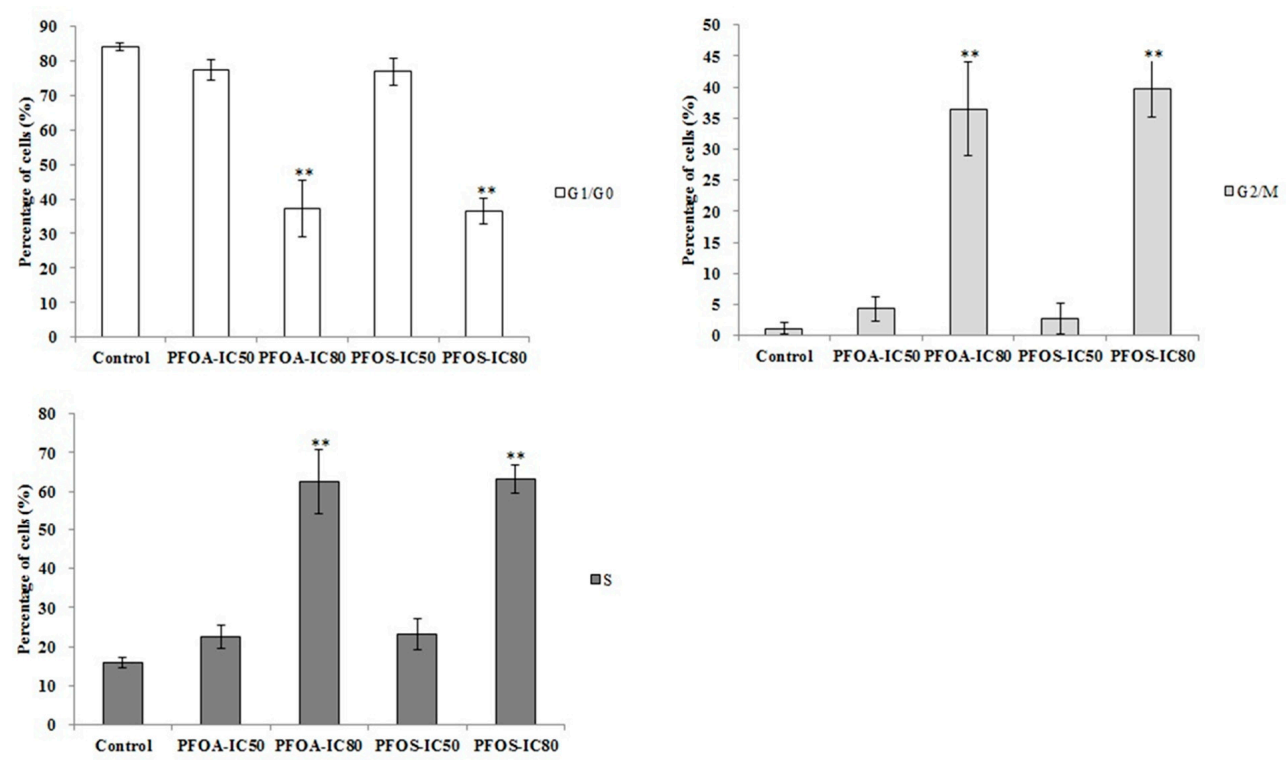

Figure 4. Cell cycle of ZFL under the inducing of PFOA and PFOS. The experiment was repeated three times. ${ }^{* *} p<0.01$.

\subsection{Protein Expression Levels of p53,Bcl-2, and Active-Caspase 3 in ZFL Cells Induced with PFOA} and PFOS

To determine the protein levels of p53, Bcl-2, and active-caspase 3 in PFOA or PFOS treated ZFL cells, western blotting was performed. As shown in Figure 5, p53 protein was expressed in $\mathrm{PFOA}^{-\mathrm{IC}_{50}}$ 
and PFOS-IC 80 groups and $\mathrm{Bcl} 2$ was expressed in all groups, in spite of a lower expression in the $\mathrm{PFOS}_{-} \mathrm{IC}_{80}$ group. For active-caspase 3 , the expression in PFOA-IC ${ }_{50}, \mathrm{PFOA}-\mathrm{IC}_{80}, \mathrm{PFOS} \mathrm{IC}_{50}$ and PFOS-IC 80 groups were comparable.

\section{P53}

$\mathrm{BCl}-2(6 \mathrm{~B} 5)$

Active-Caspase 3
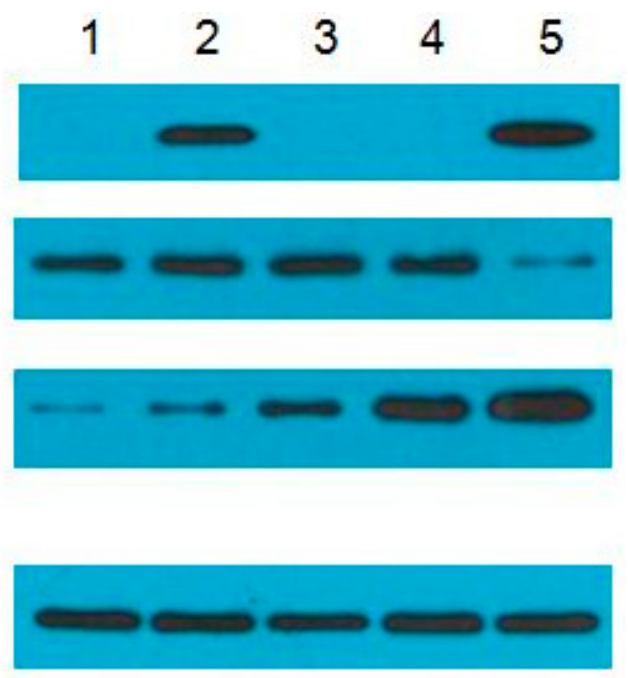

Figure 5. Protein expression level of $\mathrm{P} 53, \mathrm{Bcl}-2$ and Caspase-3. 1, Control group; $2, \mathrm{PFOA}-\mathrm{IC}_{50}$ group; 3, PFOA-IC 80 group; 4 , PFOS-IC 50 group; 5 , PFOS-IC 80 group. ZFL cells were treated with PFOA or PFOS at $\mathrm{IC}_{50}$ or $\mathrm{IC}_{80}$ concentrations for $48 \mathrm{~h}$. The protein expressions of $\mathrm{p} 53$, caspase 3 and $\mathrm{Bcl}-2$ were detected. GAPDH was used as an internal control.

\section{Discussion}

Although zebrafish is a mostly-widely model organism in laboratories, zebrafish cell lines are still unexploited and limited in applications, partly due to their unknown genetic and physiological properties. In this study, ZFL cells were treated with either PFOA or PFOS for $48 \mathrm{~h}$. Results showed that both PFOA and PFOS were able to induce apoptosis in zebrafish liver cells.

p53, Bcl-2, Bax, caspase-3 and NF- $\mathrm{kB}$ p65 are key genes in the process of cell apoptosis. In the present study, we aimed to confirm that the mRNA and protein expression of these key genes in the pathway are altered and also aimed to further explore the effects of PFOA and PFOS in promoting apoptosis in the different dose groups.

The p53 protein plays a critical role in cell cycle arrest and apoptosis, and its loss or inactivation is common in human cancers [24-27]. Consequently, therapies to restore p53 function, particularly its ability to induce apoptosis, have been a research focus. p53 is a tumor suppressor gene, and contributes to DNA repair and cell apoptosis [28-31]. Moreover, p53 plays an important role in DNA damage and apoptosis induced by UV and chemical agents. Importantly, p53 has already been cloned in zebrafish and was confirmed to be expressed in the embryogenesis stage. Other studies identified the p53 pathway as the essential mediator of the elevated apoptosis in the developing zebrafish [32]. After stimulated with PFOA and PFOS, the gene expression of p53 increased. We attributed this to a transcriptional event because the mRNA level of $\mathrm{p} 53$ was induced upon treatment with PFOA-IC 50 , PFOA-IC 80, PFOS-IC $_{50}$ and PFOS-IC 80 in ZFL cells (Figure 2). Consistent with an increase in mRNA, the protein level of p53 also significantly increased in PFOA-IC 50 and PFOS-IC 80 groups (Figure 5). These results indicated that PFOS and PFOA induced apoptosis in ZFL cells, presumably though the p53 pathway.

Some Bcl-2 family members are channel proteins and are located in the outer membrane of the mitochondria, endoplasmic reticulum and nuclear membrane, as well as the cytosol [33]. Depending on their function to inhibit or promote apoptosis, the Bcl gene family can be divided into apoptosis inhibiting genes (including Bcl-2 and Bcl-XL), and apoptosis promoting genes (including Bax, Bad 
and Bxl-XS) [34,35]. Prior to cell apoptosis, Bax is located within the cytoplasm. Upon receiving clues to induce cell death, Bax goes into the outer mitochondrial membrane and forms a specific channel to facilitate the release of cytochrome c. Conversely, Bcl-2's functions are to prevent the release of cytochrome $\mathrm{c}$ in this process. Together Bax and Bcl-2 regulate and mediate the process by which mitochondria contributes to cell death, known as the intrinsic apoptosis pathway [36]. This pathway is required for preventing cancer and for normal embryonic development [36]. In our study, Bcl2 was found to be highly expressed in ZFL cells, whereas the expression of Bax was relative low. ZFL cells treated with PFOA and PFOS expressed higher levels of Bcl-2 (Figures 2 and 5). Anti-apoptotic response were made, and activated the expression of Bcl2. However, large amounts of apoptosis cell were eventually proved and detected by flow cytometry, indicating that $\mathrm{Bcl} 2 \mathrm{mRNA}$ is not effectively translated into apoptotic inhibition proteins.

Members of the caspase family of aspartic acid-directed cysteine proteases lead to the loss of cellular structure and function and eventually result in apoptotic cell death [37,38]. In mammalian cells, the caspase family is comprised of at least 14 enzymes, which can be divided into two categories: initiator caspases and executioner caspases, depending on where they function in the apoptotic cascade [39]. Caspase-3, the essential effector caspase, plays a pivotal role during caspase-dependent apoptosis. The main function of caspase is to hydrolyze proteins and connect the caspase cascade in the upstream and downstream apoptotic process. Amino acids of caspase- 3 in zebrafish have great homology with vertebrates. In our study, the mRNA level of caspase 3 was induced with the treatment of PFOA and PFOS (Figure 2), and the protein level of pro-caspase 3 increased in the PFOA-IC 50 group and the PFOS-IC 80 group (Figure 5). These results revealed that PFOS and PFOA induced apoptosis in ZFL cells with involvement of caspases [22].

To sum up, this study confirmed the crucial genes in the pathway of apoptosis and further illustrated the effects of PFOA and PFOS on the process of apoptosis. It provides a theoretical basis for future study of cell apoptosis.

\section{Conclusions}

According to the results in this study, we noted that PFOA-IC 80 and PFOS-IC $\mathrm{I}_{50}$ both promoted apoptosis. The decreased percentage of cells in G1/G0 stage and the increased percentage of cells in G2/M stage clearly showed that cell cycle and cell proliferation were blocked in both the PFOA-IC 80 and PFOS-IC 80 groups. This study confirmed the crucial genes in the pathway of apoptosis and further illustrated the effect of PFOA and PFOS in the process of apoptosis.

Acknowledgments: This work was supported by grants from Chinese Academy of Inspection and Quarantine (No. 2013JK013), General Administration of Quality Supervision, Inspection and Quarantine (AQSIQ) of People's Republic of China (No. 201510203-02), and General Administration of Quality Supervision, Inspection and Quarantine (AQSIQ) of People's Republic of China (No. 201510024).

Author Contributions: Yuan Cui designed the study, performed statistical analysis and wrote the manuscript. Wei Liu, Wenping Xie and Cheng Wang performed the date collection and wrote the manuscript. Wenlian Yu and Huiming Chen conducted the research and revised the manuscript. All of the authors contributed to the design of the study and preparation of the final version of the manuscript.

Conflicts of Interest: The authors declare no conflict of interest.

\section{References}

1. Van Ham, T.J.; Mapes, J.; Kokel, D.; Peterson, R.T. Live imaging of apoptotic cells in zebrafish. FASEB J. 2010, 24, 4336-4342. [CrossRef] [PubMed]

2. Hilger-Eversheim, K.; Moser, M.; Schorle, H.; Buettner, R. Regulatory roles of AP-2 transcription factors in vertebrate development, apoptosis and cell-cycle control. Gene 2000, 260, 1-12. [CrossRef]

3. Bonneau, B.; Nougarède, A.; Prudent, J.; Popgeorgiev, N.; Peyriéras, N.; Rimokh, R.; Gillet, G. The Bcl-2 homolog Nrz inhibits binding of IP3 to its receptor to control calcium signaling during zebrafish epiboly. Sci. Signal. 2014, 7. [CrossRef] [PubMed] 
4. Coffin, A.B.; Rubel, E.W.; Raible, D.W. Bax, Bcl2, and p53 differentially regulate neomycin-and gentamicin-induced hair cell death in the zebrafish lateral line. J. Assoc. Res. Otolaryngol. 2013, 14, 645-659. [CrossRef] [PubMed]

5. Chua, J.; Liew, H.; Guo, L.; Lane, D. Tumor-specific signaling to p53 is mimicked by Mdm2 inactivation in zebrafish: Insights from $\mathrm{mdm} 2$ and mdm4 mutant zebrafish. Oncogene 2015, 34, 5933-5941. [CrossRef] [PubMed]

6. Yuan, Y.; Sun, H.; Ge, S.; Wang, M.; Zhao, H.; Wang, L.; An, L.; Zhang, J.; Zhang, H.; Hu, B. Controlled intracellular self-assembly and disassembly of $19 \mathrm{~F}$ nanoparticles for MR imaging of caspase 3/7 in zebrafish. ACS Nano 2014, 9, 761-768. [CrossRef] [PubMed]

7. Wu, S.; Ji, G.; Liu, J.; Zhang, S.; Gong, Y.; Shi, L. TBBPA induces developmental toxicity, oxidative stress, and apoptosis in embryos and zebrafish larvae (Danio rerio). Environ. Toxicol. 2015. [CrossRef] [PubMed]

8. De Felip, E.; Abballe, A.; Albano, F.L.; Battista, T.; Carraro, V.; Conversano, M.; Franchini, S.; Giambanco, L.; Iacovella, N.; Ingelido, A.M. Current exposure of Italian women of reproductive age to PFOS and PFOA: A human biomonitoring study. Chemosphere 2015, 137, 1-8. [CrossRef] [PubMed]

9. Van de Vijver, K.I.; Hoff, P.; Das, K.; Brasseur, S.; Van Dongen, W.; Esmans, E.; Reijnders, P.; Blust, R.; De Coen, W. Tissue distribution of perfluorinated chemicals in harbor seals (Phoca vitulina) from the Dutch Wadden Sea. Environ. Sci. Technol. 2005, 39, 6978-6984. [CrossRef] [PubMed]

10. Yeung, L.W.; So, M.; Jiang, G.; Taniyasu, S.; Yamashita, N.; Song, M.; Wu, Y.; Li, J.; Giesy, J.; Guruge, K. Perfluorooctanesulfonate and related fluorochemicals in human blood samples from China. Environ. Sci. Technol. 2006, 40, 715-720. [CrossRef] [PubMed]

11. Schaefer, C.E.; Andaya, C.; Urtiaga, A.; McKenzie, E.R.; Higgins, C.P. Electrochemical treatment of perfluorooctanoic acid (PFOA) and perfluorooctane sulfonic acid (PFOS) in groundwater impacted by aqueous film forming foams (AFFFs). J. Hazard. Mater. 2015, 295, 170-175. [CrossRef] [PubMed]

12. Loccisano, A.E.; Longnecker, M.P.; Campbell, J.L., Jr.; Andersen, M.E.; Clewell, H.J., III. Development of PBPK models for PFOA and PFOS for human pregnancy and lactation life stages. J. Toxicol. Environ. Health Part A 2013, 76, 25-57. [CrossRef] [PubMed]

13. Abdellatif, A.; Al-Tonsy, A.H.; Awad, M.E.; Roberfroid, M.; Khan, M. Peroxisomal enzymes and 8-hydroxydeoxyguanosine in rat liver treated with perfluorooctanoic acid. Dis. Mark. 2003, 19, 19-25. [CrossRef]

14. Kennedy, G.L.; Butenhoff, J.L.; Olsen, G.W.; O'Connor, J.C.; Seacat, A.M.; Perkins, R.G.; Biegel, L.B.; Murphy, S.R.; Farrar, D.G. The toxicology of perfluorooctanoate. Crit. Rev. Toxicol. 2004, 34, 351-384. [CrossRef] [PubMed]

15. Directorate, O.E. Hazard Assessment of Perfluorooctane Sulfonate (PFOS) and Its Salts: ENV/JM/RD (2002) 17/FINAL; Organisation for Economic Co-operation and Development: Paris, France, 2002.

16. Seacat, A.M.; Thomford, P.J.; Hansen, K.J.; Olsen, G.W.; Case, M.T.; Butenhoff, J.L. Subchronic toxicity studies on perfluorooctanesulfonate potassium salt in cynomolgus monkeys. Toxicol. Sci. 2002, 68, 249-264. [CrossRef] [PubMed]

17. Guruge, K.S.; Yeung, L.W.; Yamanaka, N.; Miyazaki, S.; Lam, P.K.; Giesy, J.P.; Jones, P.D.; Yamashita, N. Gene expression profiles in rat liver treated with perfluorooctanoic acid (PFOA). Toxicol. Sci. 2006, 89, 93-107. [CrossRef] [PubMed]

18. Son, H.-Y.; Kim, S.-H.; Shin, H.-I.; Bae, H.I.; Yang, J.-H. Perfluorooctanoic acid-induced hepatic toxicity following 21-day oral exposure in mice. Arch. Toxicol. 2008, 82, 239-246. [CrossRef] [PubMed]

19. Shabalina, I.G.; Panaretakis, T.; Bergstrand, A.; Depierre, J.W. Effects of the rodent peroxisome proliferator and hepatocarcinogen, perfluorooctanoic acid, on apoptosis in human hepatoma HepG2 cells. Carcinogenesis 1999, 20, 2237-2246. [CrossRef] [PubMed]

20. Panaretakis, T.; Shabalina, I.G.; Grandér, D.; Shoshan, M.C.; DePierre, J.W. Reactive oxygen species and mitochondria mediate the induction of apoptosis in human hepatoma HepG2 cells by the rodent peroxisome proliferator and hepatocarcinogen, perfluorooctanoic acid. Toxicol. Appl. Pharmacol. 2001, 173, 56-64. [CrossRef] [PubMed]

21. Yao, X.; Zhong, L. Genotoxic risk and oxidative DNA damage in HepG2 cells exposed to perfluorooctanoic acid. Mutat. Res./Gen. Toxicol. Environ. Mutagen. 2005, 587, 38-44. [CrossRef] [PubMed] 
22. Liu, C.; Yu, K.; Shi, X.; Wang, J.; Lam, P.K.; Wu, R.S.; Zhou, B. Induction of oxidative stress and apoptosis by PFOS and PFOA in primary cultured hepatocytes of freshwater tilapia (Oreochromis niloticus). Aquat. Toxicol. 2007, 82, 135-143. [CrossRef] [PubMed]

23. Bopp, S.K.; Lettieri, T. Comparison of four different colorimetric and fluorometric cytotoxicity assays in a zebrafish liver cell line. BMC Pharmacol. 2008, 8. [CrossRef] [PubMed]

24. Giaccia, A.J.; Kastan, M.B. The complexity of p53 modulation: Emerging patterns from divergent signals. Genes Dev. 1998, 12, 2973-2983. [CrossRef] [PubMed]

25. Levine, A.J. p53, the cellular gatekeeper for growth and division. Cell 1997, 88, 323-331. [CrossRef]

26. Prives, C. Signaling to p53: Breaking the MDM2-p53 circuit. Cell 1998, 95, 5-8. [CrossRef]

27. Vousden, K.H. p53: Death star. Cell 2000, 103, 691-694. [CrossRef]

28. Ko, Y.-C.; Lien, J.-C.; Liu, H.-C.; Hsu, S.-C.; Lin, H.-Y.; Chueh, F.-S.; Ji, B.-C.; Yang, M.-D.; Hsu, W.-H.; Chung, J.-G. Demethoxycurcumin-induced DNA damage decreases DNA repair-associated protein expression levels in NCI-H460 human lung cancer cells. Anticancer Res. 2015, 35, 2691-2698. [PubMed]

29. Carrillo, A.M.; Hicks, M.; Khabele, D.; Eischen, C.M. Pharmacologically increasing Mdm2 inhibits DNA repair and cooperates with genotoxic agents to kill p53 inactivated ovarian cancer cells. Mol. Cancer Res. 2015, 13. [CrossRef] [PubMed]

30. Mancini, F.; Pieroni, L.; Monteleone, V.; Lucà, R.; Fici, L.; Luca, E.; Urbani, A.; Xiong, S.; Soddu, S.; Masetti, R. MDM4/HIPK2/p53 cytoplasmic assembly uncovers coordinated repression of molecules with anti-apoptotic activity during early DNA damage response. Oncogene 2015. [CrossRef] [PubMed]

31. Demoulin, B.; Hermant, M.; Castrogiovanni, C.; Staudt, C.; Dumont, P. Resveratrol induces DNA damage in colon cancer cells by poisoning topoisomerase II and activates the ATM kinase to trigger p53-dependent apoptosis. Toxicol. Vitr. 2015, 29, 1156-1165. [CrossRef] [PubMed]

32. Prykhozhij, S.V. In the absence of Sonic hedgehog, p53 induces apoptosis and inhibits retinal cell proliferation, cell-cycle exit and differentiation in zebrafish. PLoS ONE 2010, 5. [CrossRef] [PubMed]

33. Tian, X.; Zeng, G.; Li, X.; Wu, Z.; Wang, L. Cantharidin inhibits cell proliferation and promotes apoptosis in tongue squamous cell carcinoma through suppression of miR-214 and regulation of p53 and Bcl-2/Bax. Oncol. Rep. 2015, 33, 3061-3068. [CrossRef] [PubMed]

34. Yan, X.; Jiang, Z.; Bi, L.; Yang, Y.; Chen, W. Salvianolic acid A attenuates TNF- $\alpha$-and d-GalN-induced ER stress-mediated and mitochondrial-dependent apoptosis by modulating Bax/Bcl-2 ratio and calcium release in hepatocyte LO2 cells. Naunyn-Schmiedebergs Arch. Pharmacol. 2015, 388, 817-830. [CrossRef] [PubMed]

35. Zeng, J.; Chen, S.; Li, N.; Chen, L.; Su, J.; Niu, G.; Zhu, S.; Liang, Y. Sasanquasaponin from Camellia oleifera Abel. induces apoptosis via Bcl-2, Bax and caspase-3 activation in HepG2 cells. Mol. Med. Rep. 2015, 12, 1997-2002. [CrossRef] [PubMed]

36. Hardwick, J.M.; Soane, L. Multiple functions of BCL-2 family proteins. Cold Spring Harb. Perspect. Biol. 2013, 5. [CrossRef] [PubMed]

37. Walsh, J.G.; Cullen, S.P.; Sheridan, C.; Lüthi, A.U.; Gerner, C.; Martin, S.J. Executioner caspase-3 and caspase-7 are functionally distinct proteases. Proc. Natl. Acad. Sci. USA 2008, 105, 12815-12819. [CrossRef] [PubMed]

38. González, D.; Espino, J.; Bejarano, I.; López, J.; Rodriguez, A.; Pariente, J. Caspase-3 and-9 are activated in human myeloid HL-60 cells by calcium signal. Mol. Cell. Biochem. 2010, 333, 151-157. [CrossRef] [PubMed]

39. Kuranaga, E. Caspase signaling in animal development. Dev. Growth Differ. 2011, 53, 137-148. [CrossRef] [PubMed]

(C) 2015 by the authors; licensee MDPI, Basel, Switzerland. This article is an open access article distributed under the terms and conditions of the Creative Commons by Attribution (CC-BY) license (http:/ / creativecommons.org/licenses/by/4.0/). 